Ojok, Patrick. Access And Utilization Of Information And Communication Technology By Students With Visual Impairment In Uganda's Public Universities. Indonesian Journal of Disability Studies (IJDS).2018: Vol. 5(1): PP $65-81$.

\title{
ACCESS AND UTILIZATION OF INFORMATION AND COMMUNICATION TECHNOLOGY BY STUDENTS WITH VISUAL IMPAIRMENT IN UGANDA'S PUBLIC UNIVERSITIES
}

\author{
Patrick Ojok
}

Department of Community and Disability Studies, Kyambogo University, Uganda

\begin{abstract}
The centrality of information and communication technology in enhancing inclusive teaching and learning makes their access and use an imperative for all students at all levels of education.Persons with visual impairment tend to face major barriers in using the same ICT devices that ordinary persons and other disabled persons can use. A quantitative study was conducted with 35 students with visual impairment enrolled in two public universities in Uganda to explore the extent to which they accessed and utilized ICTs. Data was collected using face-to-face interviews and analyzed using IBM SPSS version 20. The study found that most of the students were intermediate ICT users $(40 \%)$ or beginners $(37 \%)$, while a majority $(70.4 \%)$ connected to the internet via WIFI hotspots. More than half of the students $(60 \%)$ knew that their university had an e-learning platform, but a majority of the students had never uploaded/downloaded any learning materials from their universities' websites. Less than half of the students $(46 \%)$ were confident to produce text using a word processing program but only few could use power point $(12 \%)$ and excel $(8.6 \%)$ applications. To improve students with disabilities' access and use of ICTs, multiple actions are required, including equipping departments with computers, ensuring the computers are in accessible locations, giving the students opportunity to practice, and purchasing licensed adapted software applications.
\end{abstract}

Keywords: Information and communication technology, Uganda, visual impairment, university

\section{Introduction}

The role of information and communication technologies (ICT) to foster inclusive education for learners with disabilities and improve their quality of life is globally recognized. As such, access to ICTs that support participation in learning opportunities for learners with disabilities is an international policy imperative (UNSECO, 2014). The World Summit of the Information Society $(2003 ; 2005)$ affirms that ICTs should be used in all sectors of education and training as technology skills are essential for global citizenship. Although national and international legislations recognize the right of persons with disabilities

* Corresponding author: Patrick Ojok

patriceojok@yahoo.com

Published online at http://IJDS.ub.ac.id/2018

Copyright $\odot$ 2018PSLD UB Publishing. All Rights Reserved (PWDs) to ICT, in practice, PWDs, face a myriad of barriers in accessing such as: physical barriers when ICTs and learning environments are not accessible; content barriers that may occur when the content is presented in formats that are not accessible by certain PWDs, and financial barriers relating to the cost of devices, hardware and software. (UNESCO, 2014).

Even though all PWDs encounter barriers in accessing or using ICT, persons with visual impairment face the major accessibility barriers (Indongo and Mufune, 2011). For example, learning materials designed for sighted learners are often unsuitable for those with vision impairment (Permvattana, 2012), unless they are modified to suit their needs. In many cases, texts provided are too small, color graphics are of little value unless accompanied by text or audio description and interactive web sites ripe with numerous navigation challenges (Permvattana, 2012). This calls for deliberate efforts to develop contents in accessible formats and/or use software to convert ordinary contents to accessible formats.

As governments rapidly move towards digitalizing services, universities have no option but to digitalize their services such as admissions, financial management, teaching and learning, assessment and management of students' records. Many universities now require all students to apply, enroll, register, 
and make payments strictly via the online systems. Lecturers too, are required to use virtual learning platforms for teaching and manage examinations results. The way in which websites are designed can have a huge impact particularly on people with visual impairments (United Kingdom's Parliamentary Office of Science and Technology, 2012). The shift to online learning arrangements must not leave behind any students with disabilities.

Uganda has enacted national legislation aimed at increasing access to higher education to students with disabilities. According to the University and Tertiary Institutions Act 2001, a public university must take affirmative action in favor of marginalized groups on the basis of gender, disability and disadvantaged schools. (Republic of Uganda, 2001). One such affirmative action is the disability ticket whereby the Public Universities Joint Admissions Board admits 64 students with disabilities every academic year on government scholarship. This is in addition to those who admitted on merit, on private or government sponsorship, having met the standard admissions requirements. Consequently, the number of students with disabilities accessing universities and other higher education institutions in Uganda is rising. In Uganda however, inclusive education practices (at least as far training and recruitment of teachers is concerned), are limited to the primary school level. This means that inclusive learning arrangements at higher education level are the discretion of the individual institution.

Although the literature shows a great number of ICT initiatives for people with all kinds of disabilities, there is lack of research into the usability of the various applications developed (Khan, Hasan \& Clement, 2012), and even less concerning the barriers that higher education students with certain disabilities encounter. It is acknowledged that merely providing technology does not automatically create a need for it, nor does it foster a culture of using the technology. (Hosman, 2010). Against this background, the primary purpose of this study was to determine the extent of access and utilization of ICT by students with visual impairment in public universities in Uganda. The research question investigated was: to what extent are students with visual impairments accessing and utilizing ICT services in the teaching and learning processes in Uganda's public universities? Knowledge of ICT access and use ICT will help to inform policy and programmatic interventions at national and institutional levels.

\section{Literature Review}

ICT is a generic term that encompasses a range of technologies including audio, video, television, standard personal computers, and specialized adapted technologies designed for individual use. (Casely-Hayford \& Lynch, 2003). It includes internet services, telecommunications equipment and services, information technology equipment and services, media and broadcasting, libraries and documentation centres, commercial information providers, network-based information services, and other related information and communication activities. (United Nations,1999). According to the World Bank (2002), ICT consists of hardware, software, networks, and media for collection, storage, processing, transmission, and presentation of information (voice, data, text, images). As applied to education, ICT entails technologies like computers, the Internet, broadcasting technologies (radio and television), and telephony that can facilitate not only delivery of instruction, but also learning processes. (Khan, Hasan \& Clement, 2012).

There is unanimity in the literature that there exists a disparity in ICT access and use across populations and nations. Disparity in ICT access and use is often referred to as the digital divide, i.e. the gap between those with ready access to ICT tools and the knowledge that they provide access to, and those without such access or skills. (Cullen, 2001). The digital divide exists in both developed and developing countries alike. For example, in the United States, PWDs are less likely to live in households with computers, to use computers and to be online. (Dobransky \& Hargittai, 2006). It nearly affects all population groups such as people with low incomes, people with few educational qualifications or with low literacy levels, the unemployed, elderly people, people in isolated or in rural areas, PWDs, sole parents, elderly people, women and girls (Cullen, 2001). Generally, not enough attention is paid to the application of ICT for PWDs. 
(Hamid, Jamali \& Nicholas, 2006). Persons with visual impairment tend to face major accessibility barriers in using ICT in their daily life. (Indongo and Mufune, 2011; Fuglerud, 2011).

\subsection{Benefits of ICT in education for persons with disabilities}

Education is said to be the driving force of economic and social development in any country (Cholin, 2005; Mehta and Kalra, 2006). Teaching through ICT has been shown to be more cost effective than traditional programmes in developing countries, especially in terms of unit costs for large student populations. (Casely-Hayford \& Lynch, 2003). The application of ICT in education can transform teaching and learning into an engaging and active process connected to real life, and prepare students with the skills necessary to enter the workplace (Cuban, 2001, pp. 14-15). ICTs enhance higher education in a number of ways: it enables the effective storing/sorting of information, and can offer new fast ways of communication; enables the reduction of information quantity towards a higher quality; it can be integrated into teaching and learning strategies - and used to support relative learning theories; ICT can be used to create new types of interactive learning media for improved quality, equity, and access in higher education (Rosswall, 1999).

Florian (2004) described some of the direct benefits of ICT to learners with special educational needs. It enables communication, for example, assistive technologies like speech synthesizers help pupils communicate. ICT has the potential to remove the barriers leading to the problems of low rate of education in any country. It can be used as a tool to overcome the issues of cost, less number of teachers, and poor quality of education as well as to overcome time and distance barriers (McGorry, 2002). ICT can make a tremendous difference in the lives of individuals with visual impairments, improving educational and employment opportunities, enhancing social life, and facilitating independence. (Fuglerud, 2011).

In spite of its numerous benefits in education as well as other domains, ICTs are not to be taken as a panacea, i.e. their presence or use do not automatically guarantee quality learning and/or teaching (Hattangdi, \& Ghosh, 2008; Hosman, 2010). Hosman (2010) cautions that merely providing ICT does not automatically create a need for it, nor does it foster a culture of use. Thus, if not used with care, ICTs may lead to unintended consequences in education. Hattangdi, \& Ghosh, (2008) numerates the risks that may arise from using ICT: it may create a digital divide within class as students who are more familiar with ICT willreap more benefits and learn faster than those who are not ICT literate; It may shift the attention from the primary goal of the learning process to developing ICTskills, which is the secondary goal; It can affect the bonding process between the teacher and the student as ICT replaces face-to-face conversation as acommunication tool.Also since not all teachers are experts in ICT, they may be lax in updating the coursecontent online which can slow down learning among students. $\mathrm{He}$ also points out that the potential of plagiarism can be high as student can copy information rather than learning and developing their own skills.

\subsection{Barriers to ICT use for PWDs}

Access to the Internet by PWDs is steadily increasing and is now seen as a human rights issue, but disability remains one of the grounds for being unable to access both ICT and the internet. (Lenhart \& Horrigan, 2003). Although learners with disabilities face varying difficulties both in accessing and using elearning tools, the types of barriers encountered may vary according to the type of impairment. (Bocconi, Dini, Ferlino, Martinoli, \& Ott, 2007).For example, while physical disabilities inhibit keyboard use, visual impairment inhibits screen use and learning disabilities prevent large numbers of users from participating in the benefits of the Internet and its rich resources. Moreover, there are different types of accessibility: even if PWDs have physical Internet access, the hardware or software providing the Internet access may not be configured to allow those with disabilities to use it. (World Wide Web Consortium 2004). To overcome accessibility barriers, many PWDs require assistive technology to use computers and the Internet (Mann et al. 2005; World Wide Web Consortium 2004). Blind individuals for 
example, use screen reading programs such as JAWS and/or refreshable Braille displays to read what is on the screen. (D'Amour, 2004). The lack of these devices by an individual or an educational institution may mean that individuals with disabilities cannot access certain resources online.

Another barrier to ICT access and use by PWDs is related to cost. Adaptive technologies that are usable by PWDs are sometimes expensive, and is worsened by the fact that PWDs have less income than those without disabilities (Lenhart \& Horrigan, 2003).The high costs of computer hardware and software explains why PWDs are much less likely to own a computer at home than those without disabilities. A survey in the United States found that the least equipped households were households with people who had serious disabilities. (Dobransky \& Hargittai, 2006).

Especially in African countries, disparities in internet access are largely explained by the extent of national telecommunication coverage and the quality of networks (Kouadio, 2008; Cullen, 2003; Cullen, 2001). This is so because the Internet is dependent upon the quality of the underlying telecommunications infrastructure. In Uganda for example, telecom services have expanded rapidly recently, but coverage and strength of network still vary by geographical location. Internet signals are typically poorer in remote, rural and hard to reach areas where telecommunication coverage is limited and networks are poorer.

\section{Methods}

The study utilized a cross sectional survey design involving only public universities where students with visual impairments were enrolled at the time of study. All public universities were contacted to determine whether and how many students with visual impairment they enrolled. The only qualification for a student to participate was having visual impairment and being enrolled in a public university at the time of this study. Once a list of students with visual impairment was obtained from the relevant university authorities, a census survey was conducted, meaning that all the willing students with visual impairment from a participating public university were eligible. Considering that the participants were all vision impaired, data for this study were collected using face-to- face interview questionnaires. Data were analyzed using IBM SPSS statistics version 20. This being an exploratory study aimed at determining the extent of access to ICT services, descriptive statistics (frequencies, mean, mode, and standard deviation) were.

\section{Results}

\subsection{Participants' characteristics}

A total of 35 students with visual impairments participated in this study. There were slightly more females $(57 \%, \mathrm{n}=20)$ than males $(43 \%, \mathrm{n}=15)$. A majority of the students $(74 \%, n=26)$ were aged between 18 to 25 years, and the rest were aged between 26 to 35 years $(20 \%)$ and 36 to 45 years $(6 \%)$. Most of the students were in their second year of studies $(40 \%, n=14)$, followed by third years $(34 \%)$, first years (23\%), and fourth year (3\%). In terms of study sponsorship, 27 of the students (77\%) were government sponsored and only 8 students $(23 \%)$ were privately sponsored. Among the private sponsored students, nearly half $(38 \%, n=3)$ sponsored themselves while the rest were sponsored either by their biological parents $(25 \%)$, a sibling $(13 \%)$ or other relative $(25 \%)$. Although there are 9 public universities in Uganda where a person with visual impairment can enroll for university education, thestudents with visual impairment in this study enrolled in only two of the public universities, i.e., Makerere University (51\%) and Kyambogo University (49\%). Participants were also asked to rate their levels of computer proficiency. Most of the study participants were either intermediate ICT users $(40 \%, \mathrm{n}=14)$ or beginners $(37 \%, \mathrm{n}=13)$. One student $(3 \%)$ rated his/her ICT skill as an expert in ICT while only 1 student had no ICT skill at all. Seventeen percent $(n=6)$ rated themselves as advanced ICT users. When asked about the type of internet connections they used, a majority of the students $(74.3 \%, \mathrm{n}=26)$ used wifi hotspots, $20 \%$ used mobile dataconnection. Regarding the students' use of adapted ICT software for learning, a significant proportion $(85 \%, \mathrm{n}=$ $86 \%, \mathrm{n}=5$ ) used JAWS as a screen reader and the rest $(14 \%, n=5)$ used other unspecified screen readers. A high proportion of the students did not use any of the screen magnifiers presented to them. The types ofscreen magnifiers the participants used included zoom+ (17\%), desktop zoom (17\%), zoom text (2.9\%) and magic (3\%).

Table I. Participants' Characteristics $(\mathrm{N}=35)$ 
IJDS 2018; Vol. 5 No. 1, May 2018, pp. 65-80

ISSN: $2355-2158$

\begin{tabular}{|c|c|c|c|}
\hline Characteristic & & $\mathbf{n}$ & $\%$ \\
\hline \multirow[t]{2}{*}{ Gender } & Male & 15 & 42.9 \\
\hline & Female & 20 & 57.1 \\
\hline \multirow[t]{3}{*}{ Age (years) } & $18-25$ years & 26 & 74.3 \\
\hline & $26-35$ years & 7 & 20 \\
\hline & $36-45$ years & 2 & 5.7 \\
\hline \multirow[t]{2}{*}{ Sponsorship type } & Government Sponsored & 27 & 77.1 \\
\hline & Private Sponsored & 8 & 22.9 \\
\hline \multirow[t]{4}{*}{ If private, who is financing your studies? } & Biological parents & 2 & 25 \\
\hline & Sibling & 1 & 12.5 \\
\hline & Relative & 2 & 25 \\
\hline & Myself & 3 & 37.5 \\
\hline \multirow[t]{2}{*}{ University } & Makerere University & 18 & 51.4 \\
\hline & Kyambogo University & 17 & 48.6 \\
\hline \multirow[t]{5}{*}{ Computer Proficiency } & Expert & 1 & 2.9 \\
\hline & Advanced & 6 & 17.1 \\
\hline & Intermediate & 14 & 40 \\
\hline & Beginner & 13 & 37.1 \\
\hline & None & 1 & 2.9 \\
\hline \multirow[t]{2}{*}{ What screen reader do you use? } & JAWS & 30 & 85.7 \\
\hline & Other & 5 & 14.3 \\
\hline \multirow[t]{5}{*}{ What screen magnifier do you use? } & Zoom text & 1 & 2.9 \\
\hline & Zoom+ & 6 & 17.1 \\
\hline & Magic & 1 & 2.9 \\
\hline & Desktop zoom & 6 & 17.1 \\
\hline & None & 21 & 60 \\
\hline \multirow[t]{4}{*}{ Internet Connection type } & Broadband & 1 & 2.9 \\
\hline & Mobile broadband & 7 & 20 \\
\hline & Wifi Hotspot & 26 & 74.3 \\
\hline & None & 1 & 2.9 \\
\hline
\end{tabular}

69

Cite this as:

Ojok, Patrick. Access And Utilization Of Information And Communication Technology By Students With Visual Impairment In Uganda's Public Universities. Indonesian Journal of Disability Studies (IJDS).2018: Vol. 5(1):

PP 65 - 80. 


\subsubsection{Study Programs}

The 35 students with visual impairmentwere enrolled inonly seven bachelorsdegree programs (86\%)and three ordinary diploma programs (14\%). Figure 1 shows that a majority of the students were pursuing the Bachelor of Arts in Education $(29 \%, n=10)$, followed by the Bachelor of Arts degree in Guidance and counseling $(20 \%, n=$ 7). All the students enrolled in the diploma programs, and those pursuing the bachelor of guidance and counseling were from Kyambogo University.Likewise, the students pursuing the degree in law, community psychology and social work and social administration were all from Makerere University.

\subsection{Use of ICT at University}

This section presents findings relating to elearning platforms, access to ICT equipment in class, and ICT based activities used in class. Findings are presented in Table III.

\subsubsection{Access to e-learning platforms}

To establish students' access to e-learning platforms, two questions were asked: Does your university have an e-learning platform or virtual learning environment? Can you easily log in and out of it at home and at campus? Findings to these questions are shown in Table $\mathrm{V}$. Generally, more than half of the students $(60 \%)$ knew that their university had an e-learning platform. Six percent said there was no elearning platform while $34 \%$ were not sure. However, e-learning platforms are not accessible to most of the students both on campus $(67 \%)$ and off-campus (79\%). At institutional level, more students from Kyambogo University (78\%) than Makerere University (7\%) said that it was easy to log onto the e-learning platform while at campus. A significant number of Makerere University students $(93 \%, n=14)$ said that it was not easy to access their University's e-learning platform while off-campus, compared with $57 \%$ of Kyambogo students who said the same. Generally, a majority of the students (79\%) don't find it easy to access e-learning platformsin places outside of university.

\subsubsection{ICT equipment use in class}

The study sought to establishhow often the participant6s used certain ICT equipment for learning purposes during lessons.The findings show that a majority of the students tend to use ICT equipment with internet, implying that they use it to search information. For example, $(80 \%)$ never used a desktop computer with no internet connection while a small number of students used desktop computers with no internet several times $(8.6 \%)$, weekly $(8.6 \%)$, and everyday (2.9\%). On the contrary, most of the students use a desktop computer with internet several times (81.4\%), weekly (22.9\%), and everyday $(5.7 \%)$. Regarding whether the students use a recorder during class to take notes, a majority of the students (70.6\%) never used a recorder for taking notes in class. The rest of them indicated they used a recorder for taking notes several times (3\%), weekly (15\%), and everyday $(11.8 \%)$. When it comes to mobile phone use however, a majority of the students $(85 \%, n=28)$ used their own mobile phones in class everyday compared with only $12 \%(n=4)$ who never used their own mobile phone at all in class. Use of laptop with internet $(38 \%)$ or with no internet $(31 \%)$ on a daily basis was lowest among the students from both Kyambogo University and Makerere University. Although nearly half of the students $(45 \%, n=15)$ said they used their own laptop every day. Most of those who used their own laptops study in Makerere University $(61 \%, n=$ 11) compared with only $27 \%(n=4)$ from Kyambogo University.

\subsection{Skills and competencies in ICT}

Participants were asked to indicate how often they used a computer for various learning activities during lessons. As Table VII shows, there is generally limited engagement in ICT based activities among the students from both universities. For example, $41 \%$ have never sent or received emails regarding their studies, $12 \%$ do so every day, $21 \%$ do so several times and $27 \%$ send or received emails on a weekly basis. Only a small number of the students (9\%) had never searched the internet for information, compared with those who searched the internet to collect information every day (20\%), several times (17\%), and weekly (54\%). $48.6 \%$ of the respondents never download, upload or browse learning material, $5.7 \%$ do so every day, $20 \%$ do so several times and $25.7 \%$ do so weekly. Although some students acknowledged that their universities had an e-learning platform, a majority of the students have neither posted any work on an e-learning platform (83\%) nor 
participated in an online forum discussion (62\%). This means that e-learning platforms exist in universities but are not utilized for learning purposes.

\subsection{Impact of ICT on learning}

Participants were asked to indicate whether using ICT during lessons had a positive impact on various learning tasks. Table IX revealed that slightly less than half of the students $(44 \%$, $\mathrm{n}=15$ ) indicated that ICT helps them a lot to concentrate more on what they learn, against only $11.8 \%, n=4)$ who indicated that it does not. On whether ICT Helps to feel more independent in learning, the majority $(69 \%, \mathrm{n}=$ 24) said it does a lot, $11.4 \%$ said somewhat, $8.6 \%$ little and $11.4 \%$ said ICT does not all help them to become more independent in learning. Regarding whether ICT helps to understand easily what they are learning, $47 \%$ said it helps a lot, somewhat (17\%), and a little (28.6\%). When asked if ICT helps them remember easily what they learn, $42.9 \%$ said a lot, $31.4 \%$ said somewhat, $25.7 \%$ said a little and $11.8 \%$ said ICT does not at all help them to easily remember what they learned. Students also indicated whether ICT helps them to work better with other students on tasks. 22 of the students $(63 \%)$ said that ICT helps them to work better with other students on tasks compared with only $26 \%(n=9)$ who said it helped a little.

\subsection{Attitudes towards computers}

To gauge the attitudes of the students towards computers, the following question was asked: thinking about your experience with computers, to what extent do you agree/disagree with the following statements? According to Table $\mathrm{X}$, less than half of the students $(37 \%, n=13)$ strongly agreed that they used a computer because they had an interest in it, while 2 of the students $(6 \%)$ strongly disagreed with the statement. On whether using a computer made them lose track of what they were studying, few students $(17 \%, \mathrm{n}=6)$ strongly disagreed, $31 \%$ agreed, $40 \%$ disagreed and $11 \%$ strongly agreed. Meanwhile, $62.9 \%$ of the participants strongly agreed that using a computer will help them in future as an adult, while $37.1 \%$ agreed. On whether ICT helps them to learn skills to get a job, less than half of the students (42.9\%) strongly agreed, $48.6 \%$ agreed, and only $8.6 \%$ disagreed. Slightly more than half of the students $(53 \%, \mathrm{n}=14)$ strongly agreed with the statement that they use computer because they need it for future studies against only $3(12 \%)$ who disagreed.

\section{Discussion}

The present study investigated the extent to which public university students with visual impairments in Uganda access and use ICTs in learning. The most surprising findings of this study were that the students were enrolled in only two of the public universities, namely Makerere University $(51 \%, \mathrm{n}=18)$ and Kyambogo University $(49 \%, \mathrm{n}=17)$, and that a majority of the students pursued the B.A. in Education (29\%, $\mathrm{n}=10)$ and Guidance and counseling $(20 \%, \mathrm{n}=7)$. The 35 students were enrolled in only 8 under graduate and ordinary diploma programs. Since every applicant freely chooses a university and study program at different times, it would be expected that the students enrolled in many, if not all public universities, and pursue a wider variety of academic programs. There are some plausible explanations for this situation: it is likely that both the students and/or the university admissions authoritypresumed that only Kyambogo and Makerere universities were conducive for their studies. Second, there is a tendency to admit government sponsored students to programs other than their first choice study programs. Since most of the students in the study were government sponsored, it is possible that they were denied their first choice programs, or were admitted to programs they did not necessarily apply for. A majority of the students $(77 \%, \mathrm{n}=27)$ were government sponsored and only $8(23 \%)$ were private sponsored, but this was no surprise given the relatively high cost of university education.

Regarding ICT skills and competencies, most of the students were either intermediate users $(40 \%, n=14)$ or beginners $(37 \%, n=13)$ with few advanced users $(17 \%, n=6)$. One student had no skill at all on ICT while only one student rated him/herself as an expert ICT user. These findings make sense when considering the students' rating of their confidence in specific ICT tasks. For example, only less than half of the students $(45.7 \%)$ were confident to produce text using a word 
processing program, while 6\% $(n=2)$ were unable. The least number of confident users were registered in spread sheets $(8.6 \%)$ and power point $(12 \%, n=4))$. The findings show that students with visual impairment can indeed master computer use but are still challenged by relatively advanced computer applications like power point and spread sheet. This may be explained by lack of computers at home and/or university, inaccessible computer hardware, lack of licensed adapted software, and/or high cost of owning a computer or using one in a public place such as internet cafe. Previous studies confirm that financial barriers hinder ICT use by PWDs (UNICEF, 2014; Dobransky \& Hargittai, 2006). For students with disabilities to use ICTsinhigher education, making them available at universityand addressing the skills gaps among intended users are critical. However, merely providing ICTs does not automatically create a need for it, nor does it foster a culture of using the technology.(Hosman (2010).

The findings related to internet use show a relatively good access to wifi-internet in the two universities. For example, a majority of the students $(74.3 \%, \mathrm{n}=26)$ connect to the internet via wifi hotspots. Although more than half of the students $(60 \%)$ knew that their university had an e-learning platform, generally, elearning platforms were not accessible to a majority of the students both on campus $(67 \%)$ and off-campus (79\%). It appears that the available e-learning platforms in the universities were not utilized for learning purposes, since a majority of the students indicated that they had never uploaded/downloaded any learning materials from their universities' websites. The way in which websites are designed can impact people with visual impairments (United Kingdom's Parliamentary Office of Science and Technology, 2012). It is also possible that the elearning platforms and/or the universities' websites aren't accessible for the students with visual impairment.

The study revealed that a majority of the students tended to use ICT equipment for internet connection, primarily to search information. For example, nearly the same number of students had never used a desktop computer with no internet connection $(80 \%)$, while $81.4 \%$ ) indicated they used a desktop computer with internet several times (81.4\%), weekly $(22.9 \%)$, and everyday $(5.7 \%)$. On mobile phone use however, a majority of the students $(85 \%, n=28)$ used their own mobile phones in class everyday compared with only $12 \%(n=4)$ who never used their own mobile phone at all in class. A relatively low number of the students $(37 \%, n=13)$ strongly agreed with the statement that they used a computer because they had an interest in it, while 2 of the students $(6 \%)$ strongly disagreed with the statement. It may be necessary to sensitize the students to better appreciate the value of ICT in education and life after campus. Low interestand lack of skills in ICT implies that even if computers were available, they may not utilize it for learning.

\section{Limitations of the study}

The primary limitation of this study is in its sample and methods. First, the study was conductedin only two public universities and with students with visual impairments. This means that private universities where students with visual impairment could be enrolled were excluded. Also, students with other disabilities were not targeted even though it was equally important to understand the use of ICT by other students with disabilities. The use of only quantitative method did not allow the follow up of some of the salient and surprising findings.

\section{Conclusions}

This study revealed some findings of interest that may have implications for practice and policy. For example, students with visual impairment were enrolled in only two out of nine public universities in Uganda. Likewise, most of the students were pursing education and guidance and counseling programs. It is not clear whether the students' first choices of universities and study programs were prioritized during admissions processes. It is possible that the Public University Joint Admissions Board presumed that the students with visual impairment can only study from Makerere and Kyambogo universities. According to Uganda's laws, a student with a disability can enroll at any university, and a university is obliged to meet the learning needs of student with disabilities like all other students. There is need to sensitize those 
responsible for admissions to ensure that qualified student applicants are admitted as per their choices of universities and study programs. A follow up qualitative research is needed to elicit the students' perspectives on their admissions and study programs.

The study findings showed that many of the students possessed low skills and competencies in carrying out various ICT tasks that are important to learning. For example, a large number of students were unable to use power point and spreadsheet applications. It is particularly concerning that in today's information age that relies a lot on ICT, many students were completely unable to prepare a word document, send an email to a student or lecturer, participate in online discussions or file an electronic document in a computer folder. This situation may be due to several factors including unavailability of computers, their inaccessibility where they exist or the lack of skills on the part of students. To address these issues, multiple actions are required, including equipping academic departments with computers, ensuring the computers are in accessible locations, giving the students opportunity to practice, and purchasing licensed adapted software applications to enable students with visual impairment to use computers for learning.

\section{REFERENCES}

UNESCO (2014). Model policy on inclusive ICTs for people with disabilities in education.

Indongo, N. \& Mufune, P. (2011). ICT Barriers for People with Disabilities in Namibia: Evidence from the 2011 Namibia Population and Housing Census. Review of Disability Studies: An International Journal. Vol. 11(1), pp. 51-67.

Permvattana, R. (2012). The VIVID model: accessible IT e-learning environments for the vision impaired. $\mathrm{PhD}$ Dissertation: Curtin University.

Republic of Uganda, (2001). The Universities and other tertiary Institutions Act 2001. of ict into education in developing countries: the example of Bangladesh. International Journal of Instruction. Vol.5, No., 62-80.

Hosman, L., \& Cvetanoska, M. (2010). Technology, teachers, and training: combining theory with Macedonia's experience. In Proceedings of the 4th ACM/IEEE International Conference on Information and Communication Technologies and Development (p. 20). ACM.

Casely-Hayford, L., Lynch, P., \& Initiative, A. I. K. (2003). A Review of Good Practice in ICT and Special Educational Needs for Africa. Imfundo.

Khan, M., Hossain, S., Hasan, M., \& Clement, C. K. (2012). Barriers to the introduction of ICT into education in developing countries: The example of Bangladesh. Online Submission, $5(2), \quad 61-80$.

Cullen, Rowena. "Addressing the digital divide." Online information review 25.5 (2001): 311-320.

Dobransky, K., \& Hargittai, E. (2006). The disability divide in Internet access and use Information, Communication \& Society, 9(3), 313-334.

Nicholas, D., Huntington, P., Jamali, H. R., \& Watkinson, A. (2006). The information seeking behaviour of the users of digital scholarly journals. Information Processing \& Management, 42(5), 1345-1365.

Cholin, V. S. (2005). Study of the application of information technology for effective access to resources in Indian university libraries. The International Information \& Library Review, 37(3), 189-197.

Mehta, S., \& Kalra, M. (2006). Information and Communication Technologies: A bridge for social equity and sustainable development in India. The International Information Library Review, 38(3), 147-160.

Khan, S.H., Hasan, M. \& Clement,C.K.(2012).Barriers to the introduction 
Cuban, L. (2001). Oversold and Underused: Computers in the classroom. Cambridge, MA: Harvard University.

Rosswall, T. (1999). The role of ICT in higher education at the beginning of this new millennium. Rector of the Swedish University of Agricultural Sciences, in http://online. kennis. org/eva/eva06/ictslu. htm [accessed on 31 May 2005].

McGorry, S. Y. (2002). Online, but on target? Internet-based MBA courses: A case study. The Internet and Higher Education, 5(2), 167-175. Fuglerud, K. S. (2011, July). The barriers to and benefits of use of ICT for people with visual impairment. In International Conference on Universal Access in Human-Computer Interaction (pp. 452-462). Springer, Berlin, Heidelberg.

Hattangdi, A., \& Ghosh, A. (2008). Enhancing the quality and accessibility of higher education through the use of Information and Communication Technologies. In International Conference on Emergent Missions, Resources, and the Geographic Locus in Strategy as a part of the 11th Annual Convention of the Strategic Management Forum (SMF), India 2008 (Vol. 2011, pp. 1- 14).

Hosman, L. (2010). Policies, partnerships, and pragmatism: Lessons from an ICT-in-education project in rural Uganda. Information Technologies \& International Development, 6(1), pp- 48.

Lenhart, A., \& Horrigan, J. B. (2003). Revisualizing the digital divide as a digital spectrum. IT \& Society, 1(5), 23-39.

Bocconi, S., Dini, S., Ferlino, L., Martinoli, C., \& Ott, M. (2007, July). ICT educational tools and visually impaired students: different answers to different accessibility needs. In International Conference on Universal Access in Human-Computer Interaction (pp. 491500). Springer, Berlin, Heidelberg.

World Summit on the Information Society (2005). Declaration of Principles: Building the Information Society: a global challenge in the

Cite this as:

Ojok, Patrick. Access And Utilization Of Information And Communication Technology By Students With Visual Impairment In Uganda's Public Universities. Indonesian Journal of Disability Studies (IJDS).2018: Vol. 5(1): PP $65-80$. new Millennium.

URL: http://www.itu.int/net/wsis/docs/geneva/offic ial/dop.html. 


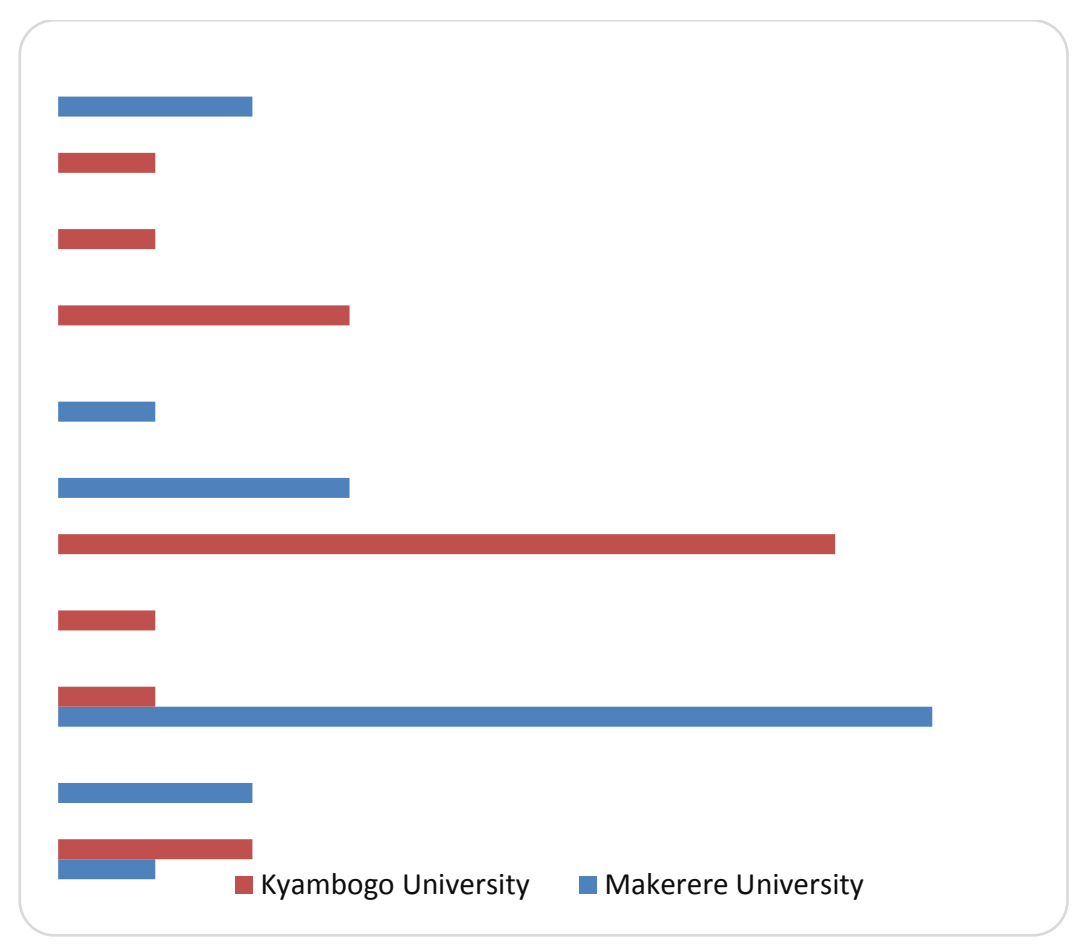

Figure 1: study programs

TABLE 2

ACCESS TO E-LEARNING $(N=35)$

\begin{tabular}{llcccccc}
\hline & & \multicolumn{3}{c}{ Makerere University } & \multicolumn{2}{c}{ Kyambogo University } & \multicolumn{2}{c}{ Total } \\
\hline Question & & $\mathrm{n}$ & $\%$ & $\mathrm{n}$ & $\%$ & $\mathrm{n}$ & $\%$ \\
\hline $\begin{array}{l}\text { Does your } \\
\text { university have }\end{array}$ & Yes & 12 & 66.70 & 9 & 52.90 & 21 & 60.00 \\
$\begin{array}{l}\text { an e-learning } \\
\text { platform? }\end{array}$ & No & 1 & 5.60 & 1 & 5.90 & 2 & 5.70 \\
$\begin{array}{l}\text { Is it easy to log } \\
\text { onto it at }\end{array}$ & Yes & 1 & 27.80 & 7 & 41.20 & 12 & 34.30 \\
campus? & No & 14 & 93.30 & 2 & 22.20 & 16 & 66.70 \\
& missing & 3 & 16.67 & 8 & 47.06 & 11 & 31.43 \\
Is it easy to log & Yes & 1 & 6.70 & 4 & 44.40 & 5 & 20.80 \\
$\begin{array}{l}\text { onto it off } \\
\text { campus? }\end{array}$ & No & 14 & 93.30 & 5 & 55.60 & 19 & 79.20 \\
& missing & 3 & 16.67 & 8 & 47.06 & 11 & 31.43 \\
\hline
\end{tabular}


TABLE 3

ICT EQUIPMENT USE IN CLASS $(N=35)$

\begin{tabular}{|c|c|c|c|c|c|c|c|}
\hline \multicolumn{2}{|c|}{$\begin{array}{l}\text { How often used certain ICT } \\
\text { equipment for learning purposes } \\
\text { during lessons? }\end{array}$} & \multicolumn{2}{|c|}{$\begin{array}{l}\text { Makerere } \\
\text { University }\end{array}$} & \multicolumn{2}{|c|}{$\begin{array}{l}\text { Kyambogo } \\
\text { University }\end{array}$} & \multicolumn{2}{|c|}{ Total } \\
\hline \multirow{5}{*}{$\begin{array}{l}\text { Desktop computer } \\
\text { with no internet } \\
\text { connection }\end{array}$} & & $\mathrm{n}$ & $\%$ & $\mathrm{n}$ & $\%$ & $\mathrm{n}$ & $\%$ \\
\hline & Never & 17 & 94.4 & 11 & 64.7 & 28 & 80.0 \\
\hline & $\begin{array}{l}\text { Several } \\
\text { times }\end{array}$ & 0 & 0.0 & 3 & 17.6 & 3 & 8.6 \\
\hline & Weekly & 1 & 5.6 & 2 & 11.8 & 3 & 8.6 \\
\hline & Everyday & 0 & 0.0 & 1 & 5.9 & 1 & 2.9 \\
\hline \multirow{4}{*}{$\begin{array}{l}\text { Desktop computer } \\
\text { with internet } \\
\text { connection }\end{array}$} & Never & 12 & 66.7 & 9 & 52.9 & 21 & 60.0 \\
\hline & $\begin{array}{l}\text { Several } \\
\text { times }\end{array}$ & 1 & 5.6 & 3 & 17.6 & 4 & 11.4 \\
\hline & Weekly & 3 & 16.7 & 5 & 29.4 & 8 & 22.9 \\
\hline & Everyday & 2 & 11.1 & 0 & 0.0 & 2 & 5.7 \\
\hline \multirow{4}{*}{$\begin{array}{l}\text { Laptop/tablet with no } \\
\text { internet connection }\end{array}$} & Never & 3 & 16.7 & 10 & 58.8 & 13 & 37.1 \\
\hline & $\begin{array}{l}\text { Several } \\
\text { times }\end{array}$ & 3 & 16.7 & 1 & 5.9 & 4 & 11.4 \\
\hline & Weekly & 3 & 16.7 & 4 & 23.5 & 7 & 20.0 \\
\hline & Everyday & 9 & 50.0 & 2 & 11.8 & 11 & 31.4 \\
\hline \multirow{4}{*}{$\begin{array}{l}\text { Laptop/tablet with } \\
\text { internet connection }\end{array}$} & Never & 4 & 22.2 & 12 & 70.6 & 16 & 45.7 \\
\hline & $\begin{array}{l}\text { Several } \\
\text { times }\end{array}$ & 3 & 16.7 & 1 & 5.9 & 4 & 11.4 \\
\hline & Weekly & 2 & 11.1 & 3 & 17.6 & 5 & 14.3 \\
\hline & Everyday & 9 & 50.0 & 1 & 5.9 & 10 & 28.6 \\
\hline \multirow[t]{3}{*}{ Own laptop } & Never & 6 & 33.3 & 10 & 66.7 & 16 & 48.5 \\
\hline & Weekly & 1 & 5.6 & 1 & 6.7 & 2 & 6.1 \\
\hline & Everyday & 11 & 61.1 & 4 & 26.7 & 15 & 45.5 \\
\hline \multirow[t]{3}{*}{ Own mobile phone } & Never & 2 & 11.8 & 2 & 12.5 & 4 & 12.1 \\
\hline & $\begin{array}{l}\text { Several } \\
\text { times }\end{array}$ & 1 & 5.9 & 0 & 0.0 & 1 & 3.0 \\
\hline & Everyday & 14 & 82.4 & 14 & 87.5 & 28 & 84.8 \\
\hline \multirow{4}{*}{$\begin{array}{l}\text { Recorder for taking } \\
\text { notes in class }\end{array}$} & Never & 14 & 77.8 & 10 & 62.5 & 24 & 70.6 \\
\hline & $\begin{array}{l}\text { Several } \\
\text { times }\end{array}$ & 0 & 0.0 & 1 & 6.3 & 1 & 2.9 \\
\hline & Weekly & 1 & 5.6 & 4 & 25.0 & 5 & 14.7 \\
\hline & Everyday & 3 & 16.7 & 1 & 6.3 & 4 & 11.8 \\
\hline
\end{tabular}


TABLE 4

ICT BASED ACTIVITIES DURING CLASS $(N=35)$

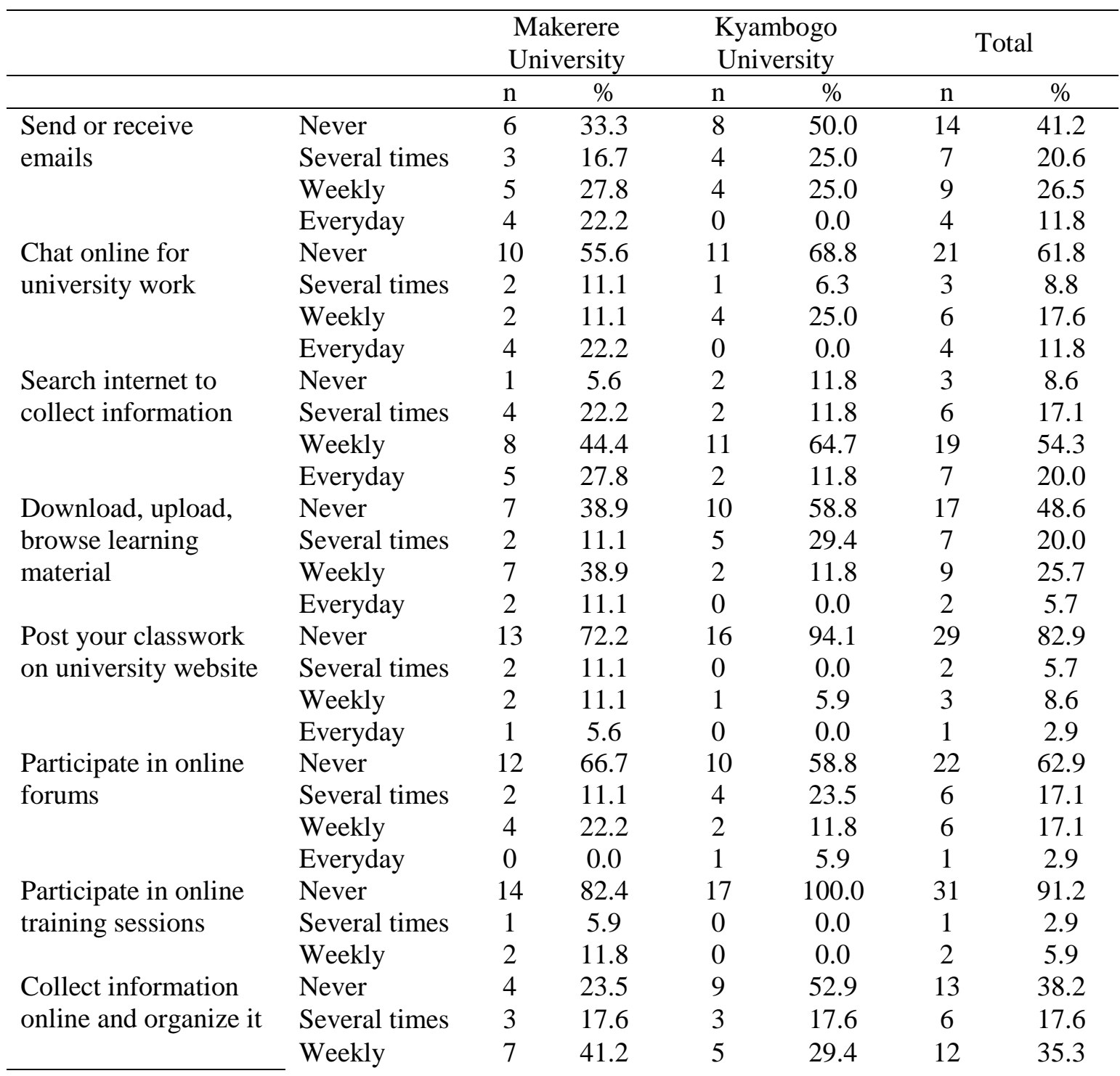


TABLE 5

SKILLS AND COMPETENCE IN USING ICT $(N=35)$

\begin{tabular}{|c|c|c|c|c|c|c|c|}
\hline \multirow{4}{*}{$\begin{array}{l}\text { Produce text using a word } \\
\text { processing programme }\end{array}$} & & \multicolumn{2}{|c|}{$\begin{array}{l}\text { Makerere } \\
\text { University }\end{array}$} & \multicolumn{2}{|c|}{$\begin{array}{l}\text { Kyambogo } \\
\text { University }\end{array}$} & \multicolumn{2}{|c|}{ Total } \\
\hline & & $\mathrm{n}$ & $\%$ & $\mathrm{n}$ & $\%$ & $\mathrm{n}$ & $\%$ \\
\hline & Not at all & 0 & 0.0 & 2 & 11.8 & 2 & 5.7 \\
\hline & A little & 3 & 16.7 & 7 & 41.2 & 10 & 28.6 \\
\hline & Somewhat & 3 & 16.7 & 4 & 23.5 & 7 & 20.0 \\
\hline & A lot & 12 & 66.7 & 4 & 23.5 & 16 & 45.7 \\
\hline Email file to another student & Not at all & 2 & 11.1 & 6 & 35.3 & 8 & 22.9 \\
\hline or lecturer & A little & 5 & 27.8 & 7 & 41.2 & 12 & 34.3 \\
\hline & Somewhat & 5 & 27.8 & 3 & 17.6 & 8 & 22.9 \\
\hline & A lot & 6 & 33.3 & 1 & 5.9 & 7 & 20.0 \\
\hline File electronic documents in & Not at all & 6 & 33.3 & 7 & 41.2 & 13 & 37.1 \\
\hline computer folders & A little & 5 & 27.8 & 5 & 29.4 & 10 & 28.6 \\
\hline & Somewhat & 3 & 16.7 & 0 & 0.0 & 3 & 8.6 \\
\hline & A lot & 4 & 22.2 & 5 & 29.4 & 9 & 25.7 \\
\hline Use spreadsheet programs & Not at all & 12 & 66.7 & 12 & 70.6 & 24 & 68.6 \\
\hline & A little & 2 & 11.1 & 2 & 11.8 & 4 & 11.4 \\
\hline & Somewhat & 2 & 11.1 & 2 & 11.8 & 4 & 11.4 \\
\hline & A lot & 2 & 11.1 & 1 & 5.9 & 3 & 8.6 \\
\hline Create a powerpoint & Not at all & 6 & 35.3 & 10 & 58.8 & 16 & 47.1 \\
\hline presentations & A little & 7 & 41.2 & 5 & 29.4 & 12 & 35.3 \\
\hline & Somewhat & 2 & 11.8 & 0 & 0.0 & 2 & 5.9 \\
\hline & A lot & 2 & 11.8 & 2 & 11.8 & 4 & 11.8 \\
\hline Participate in online & Not at all & 10 & 55.6 & 11 & 64.7 & 21 & 60.0 \\
\hline discussion program & A little & 3 & 16.7 & 3 & 17.6 & 6 & 17.1 \\
\hline & Somewhat & 4 & 22.2 & 0 & 0.0 & 4 & 11.4 \\
\hline & A lot & 1 & 5.6 & 3 & 17.6 & 4 & 11.4 \\
\hline
\end{tabular}

4 
TABLE 6

IMPACT OF ICT USE ON LEARNING $(N=35)$

\begin{tabular}{|c|c|c|c|c|c|c|c|}
\hline & & \multicolumn{2}{|c|}{$\begin{array}{l}\text { Makerere } \\
\text { University }\end{array}$} & \multicolumn{2}{|c|}{$\begin{array}{l}\text { Kyambogo } \\
\text { University }\end{array}$} & \multicolumn{2}{|c|}{ Total } \\
\hline & & $\mathrm{n}$ & $\%$ & $\mathrm{n}$ & $\%$ & $\mathrm{n}$ & $\%$ \\
\hline \multirow{4}{*}{$\begin{array}{l}\text { ICT helps concentrate } \\
\text { more on what I am } \\
\text { learning }\end{array}$} & Not at all & 4 & 22.2 & 0 & 0.0 & 4 & 11.8 \\
\hline & A little & 2 & 11.1 & 6 & 37.5 & 8 & 23.5 \\
\hline & Somewhat & 5 & 27.8 & 2 & 12.5 & 7 & 20.6 \\
\hline & A lot & 7 & 38.9 & 8 & 50.0 & 15 & 44.1 \\
\hline \multirow{4}{*}{$\begin{array}{l}\text { ICT helps me try harder } \\
\text { in what I am learning }\end{array}$} & Not at all & 2 & 11.1 & 0 & 0.0 & 2 & 5.7 \\
\hline & A little & 5 & 27.8 & 3 & 17.6 & 8 & 22.9 \\
\hline & Somewhat & 6 & 33.3 & 7 & 41.2 & 13 & 37.1 \\
\hline & A lot & 5 & 27.8 & 7 & 41.2 & 12 & 34.3 \\
\hline \multirow{4}{*}{$\begin{array}{l}\text { Feel more independent } \\
\text { in my learning }\end{array}$} & Not at all & 2 & 11.1 & 2 & 11.8 & 4 & 11.4 \\
\hline & A little & 0 & 0.0 & 3 & 17.6 & 3 & 8.6 \\
\hline & Somewhat & 2 & 11.1 & 2 & 11.8 & 4 & 11.4 \\
\hline & A lot & 14 & 77.8 & 10 & 58.8 & 24 & 68.6 \\
\hline \multirow{4}{*}{$\begin{array}{l}\text { Understand easily what I } \\
\text { am learning }\end{array}$} & Not at all & 2 & 11.1 & 0 & 0.0 & 2 & 5.7 \\
\hline & A little & 3 & 16.7 & 7 & 41.2 & 10 & 28.6 \\
\hline & Somewhat & 5 & 27.8 & 1 & 5.9 & 6 & 17.1 \\
\hline & A lot & 8 & 44.4 & 9 & 52.9 & 17 & 48.6 \\
\hline \multirow{3}{*}{$\begin{array}{l}\text { Remember more easily } \\
\text { what I have learned }\end{array}$} & A little & 4 & 22.2 & 5 & 29.4 & 9 & 25.7 \\
\hline & Somewhat & 7 & 38.9 & 4 & 23.5 & 11 & 31.4 \\
\hline & A lot & 7 & 38.9 & 8 & 47.1 & 15 & 42.9 \\
\hline \multirow{3}{*}{$\begin{array}{l}\text { ICT enables me to work } \\
\text { better with other students } \\
\text { on tasks }\end{array}$} & A little & 1 & 5.6 & 3 & 17.6 & 4 & 11.4 \\
\hline & Somewhat & 5 & 27.8 & 4 & 23.5 & 9 & 25.7 \\
\hline & A lot & 12 & 66.7 & 10 & 58.8 & 22 & 62.9 \\
\hline
\end{tabular}


TABLE 7

ATTITUDES TOWARDS COMPUTERS $\quad(N=35)$

\begin{tabular}{|c|c|c|c|c|c|c|c|}
\hline \multirow{2}{*}{$\begin{array}{l}\text { To what extent do you } \\
\text { agree/disagree with the } \\
\text { following statements? }\end{array}$} & & \multicolumn{2}{|c|}{$\begin{array}{l}\text { Makerere } \\
\text { University }\end{array}$} & \multicolumn{2}{|c|}{$\begin{array}{l}\text { Kyambogo } \\
\text { University }\end{array}$} & \multicolumn{2}{|c|}{ Total } \\
\hline & & $\mathrm{n}$ & $\%$ & $\mathrm{n}$ & $\%$ & $\mathrm{n}$ & $\%$ \\
\hline \multirow{4}{*}{$\begin{array}{l}\text { I use a computer because } \\
\text { am interested in them }\end{array}$} & Strongly Disagree & 1 & 5.6 & 1 & 5.9 & 2 & 5.7 \\
\hline & Disagree & 3 & 16.7 & 1 & 5.9 & 4 & 11.4 \\
\hline & Agree & 7 & 38.9 & 9 & 52.9 & 16 & 45.7 \\
\hline & Strongly Agree & 7 & 38.9 & 6 & 35.3 & 13 & 37.1 \\
\hline \multirow{4}{*}{$\begin{array}{l}\text { I lose track of time when } \\
\text { am studying with a } \\
\text { computer }\end{array}$} & Strongly Disagree & 3 & 16.7 & 3 & 17.6 & 6 & 17.1 \\
\hline & Disagree & 7 & 38.9 & 7 & 41.2 & 14 & 40.0 \\
\hline & Agree & 5 & 27.8 & 6 & 35.3 & 11 & 31.4 \\
\hline & Strongly Agree & 3 & 16.7 & 1 & 5.9 & 4 & 11.4 \\
\hline \multirow{7}{*}{$\begin{array}{l}\text { I use computer because it } \\
\text { will help me in future as } \\
\text { an adult } \\
\text { I use computer because it } \\
\text { will help me in the work I } \\
\text { do later on }\end{array}$} & Agree & 7 & 38.9 & 6 & 35.3 & 13 & 37.1 \\
\hline & Strongly Agree & 11 & 61.1 & 11 & 64.7 & 22 & 62.9 \\
\hline & Strongly Disagree & 1 & 5.9 & 0 & 0.0 & 1 & 2.9 \\
\hline & Disagree & 0 & 0.0 & 1 & 5.9 & 1 & 2.9 \\
\hline & Agree & 9 & 52.9 & 9 & 52.9 & 18 & 52.9 \\
\hline & Strongly Agree & 7 & 41.2 & 7 & 41.2 & 14 & 41.2 \\
\hline & missing & 1 & 5.6 & 0 & 0.0 & 1 & 5.6 \\
\hline \multirow{3}{*}{$\begin{array}{l}\text { I use computer because I } \\
\text { learn things which will } \\
\text { help me get a job }\end{array}$} & Disagree & 3 & 16.7 & 0 & 0.0 & 3 & 8.6 \\
\hline & Agree & 9 & 50.0 & 8 & 47.1 & 17 & 48.6 \\
\hline & Strongly Agree & 6 & 33.3 & 9 & 52.9 & 15 & 42.9 \\
\hline \multirow{4}{*}{$\begin{array}{l}\text { I use computer because I } \\
\text { need it for what I wish to } \\
\text { study later on }\end{array}$} & Disagree & 2 & 22.2 & 1 & 5.9 & 3 & 11.5 \\
\hline & Agree & 0 & 0.0 & 9 & 52.9 & 9 & 34.6 \\
\hline & Strongly Agree & 7 & 77.8 & 7 & 41.2 & 14 & 53.8 \\
\hline & Missing & 9 & 50.0 & 0 & 0.0 & 9 & 50.0 \\
\hline
\end{tabular}

